\title{
The Influence of Intellectual Capital, Conservatism, Earning Management, to Future Stock Return and its Implications on Stock Return (Case Study of Mining Companies in Indonesia Listed on Indonesia Stock Exchange for the Period of 2013-2018)
}

\author{
Sugiyanto ${ }^{1}$, Fitri Dwi Febrianti ${ }^{2}$, Ali Maddinsyah ${ }^{3}$, Sarwani $^{4}$, Pranoto ${ }^{5}$ \\ University Pamulang \\ dosen00495@unpam.ac.id, fitridwifebrianti@yahoo.co.id
}

\begin{abstract}
This study aims to analyze the effect of Intellectual Capital, Conservatism, and Real Earning Management on Future Stock Returns and their Implications on Stock Returns on Mining companies listed on the Indonesia Stock Exchange Period 2013 2018. This type of research is quantitative research in which this research is done by explaining the results of data from the calculation of numbers that are calculated and analyzed. The analysis used in this research is regression analysis, where regression analysis estimates the magnitude of the coefficients resulting from a linear equation involving one independent variable to be used as a predictor of the value of the dependent variable. The results of this study indicate that Intellectual capital has a significant effect on future stock returns, Conservatism has a significant effect on future stock returns, Earning management has a significant effect on future stock returns, Simultaneous results Intellectual capital, conservatism, earning management simultaneously have an effect on future stock returns, Implications future stock return on stock returns. These findings indicate that in sample companies, future stock returns on stock returns have no implications
\end{abstract}

Keywords: Intellectual Capital, Conservatism, Earning Management, Future Stock Return, Stock Return

\section{Introduction}

The era of the industrial revolution 4.0 to 5.0 and digitalization now have made the mining industry in the capital market an important factor that supports the economy in the country. The capital market facilitates the meeting of two interested parties, namely those who have funds (investors) and those who need funds (issuers) (Sugiyanto, 2019). Investors need information to assess the ability and performance of a company before making an investment decision (Sugiyanto et al, 2020. Company performance can be measured in terms of financial and non-financial. In this study, the measure of company performance used is future stock returns. stock return that shareholders have the motivation to invest their capital in the hope of getting a return (return) in accordance with the invested capital.

According to Beylin (2016) an effort to maximize stock return is the main goal of a company. This is because a high return in a company reflects the ability of the company to generate profits. The intended benefit is the profit that the company can use to develop the company's performance in the future. In addition, this profit can determine the size of the dividend paid to investors. Therefore, the return is considered to attract investors to invest 
(Beylin, 2016). Future stock returns can be interpreted as an expectation of stock returns according to the investment made. High returns will have an impact on investors, which in turn will make investors interested in investing their funds in the capital market. If seen from the high rate of return that the company will give to investors, it will show that the company's performance. That can be said to be good, besides that with high rates of return can have a positive effect on the shares that investors have invested in the capital market.

There were several cases of accounting scandals that occurred in the country, cases of violations by several auditors, and the lack of disclosure of intellectual capital. Sugiyanto and Indra (2019) technological innovation now brings up a new view in the business world that the prosperity of a company will depend on creating transformation and capitalization of knowledge, called intellectual capital. The quality of financial statements must also be checked by external parties or public accounting firms that are independent third parties. Outside parties must have an attitude of independence will produce good audit quality, but if the opposite thing that might happen is a case of manipulation. Information about company performance can be influenced by factors such as conservatism (Kazemi, 2017). Conservatism makes earnings more predictable so that earnings become more quality, and will further increase stock returns. This contradicts (Salehi and Zareijam, 2017) which shows that there is no relationship between conservatism and stock returns.

Scott (2015) states that earnings management is a management arrangement with the presentation of earnings which aims to maximize market value through the selection of accounting policies. Mulford and Comiskey (2010) stated that in order to avoid being wrongly guessed by the market, earning management steps were taken to fit the expected trend. The point is earnings management is done to convey what should be information in the company about long-term profit trends. Stock return is able to predict the company's performance in the future with high returns that can produce profits, where profits are able to develop the company's performance in the future. It is also able to determine the size of the distribution of dividends paid to investors. Based on the background, in the study taking the theme of conservatism, intellectual capital and earnings management on future stock returns has implications for stock returns.

\section{Literature Review}

James F. Stoner in Rusilowati Umi (2013: 23): states "Management is the process of planning, organizing, leading and controlling the efforts of organizational members and using all other organizational resources to activate organizational goals".

\subsection{Agency Theory}

Jensen and Meckling (1976) in Sugiyanto and Etty (2018) mentioned that agency theory explains agency problems that arise when the company owner (principal) gives authority to the management (agent). The owner and company are tasked with managing the resources owned by the owner, carrying out operational activities, and making strategic decisions in an effort to develop the company. Delegation of this task occurs due to limited resources. the owner is increasingly difficult to control all operational activities. the manager is responsible for all his efforts in managing the company and informing the owner or shareholders. (Sugiyanto 2018). 


\subsection{Signaling Theory}

Signaling theory Ross (1977) in Sugiyanto and Khomsyah (2017) emphasizes the importance of information released by companies on investment decisions outside parties. Information is an important element for investors and business people because the information essentially presents information, notes or pictures both for past, present and future conditions. (Goodfrey et al., 2016). Information published as an announcement will signal investors in making investment decisions. If the announcement contains a positive value. If the signal is positive, the market reacts, thereby increasing share prices, which in turn affects the company's performance. Furthermore, an increase in the value of shares reflects an increase in company performance, in this case stock returns, equity returns and earnings per share will increase.

\subsection{Future Stock Return}

Sugiyanto, at al 2019 stated that the greater the risk management entrepreneur, so it was said that future return has a positive relationship with risk. But high returns do not always have to be accompanied by risky investments. This can happen in a rational market. Shares (stocks) is an ownership in a company. shareholders who are entitled to the company's income and are responsible for the risk of the portion of the company that represents each share there are two types of shares namely ordinary shares and preferred shares. Ordinary shareholders have the right to choose in making decisions, such as whether or not to join another company, and receive dividends determined by management. Preferred shareholders usually do not have the rights, but receive minimum dividends. So, it can be concluded that future stock return is the expected stock return through time as current market information.

\subsection{Intelllectual Capital}

According to Stewart (1997) Ulum (2018) is a concept of capital that refers to intangible capital associated with human knowledge and experience as well as the technology used. However, according to Bontis et al (2000) in Ulum (2018) stated that researchers generally divide intellectual capital into three components, namely: Human Capital (HC), Structural Capital (SC), and Capital Employed (CE).

a) Human Capital human capital is the company's collective ability to produce the best solutions based on the mastery of knowledge and technology from its human resources. Human capital is a combination of genetic inheritance, education, experience, and attitude about life and business. This human capital will later support structural capital and employed capital (Ulum, 2018).

b) Structural Capital Structural capital is the ability of a company to meet the company's routine processes and structures related to employee efforts to produce performance According to Bontis, et.al., (2000), structural capital encompasses all non- human storehouses of knowledge in the organization. This includes databases, organizational charts, process manuals, strategies, routines and everything that makes a company's value greater than its material value in (Ulum, 2018).

c) Capital Employed This element is a component of intellectual capital that provides real value to the company. Relational capital can arise from various parts outside the corporate environment in enchancing business cooperation that can provide benefits for both parties, so as to improve the performance and value pf the company. 


\subsection{Conservatism}

Traditionally, accounting conservatism has been defined as "anticipate no profit, but anticipate all losses". (Bliss, 1924 in Watt, 2015: 208). Anticipating no profit means not recognizing profits before there is a valid claim verification of income that generates profits. This means conservatism in the extreme form because it is not allowed to recognize profit, but to admit any loss even though it has not been realized. So the profit will only be recognized when it has been realized and until there is a valid claim against the profit. Watts (2015) states, conservatism as asymmetry in the needs of verification of profits and losses. This means that there is a difference in the need to recognize the advantages and disadvantages. The greater the difference in the degree of verification needed to recognize profit compared to loss, the greater the conservatism. According to Mc Connell (2017), member of the IASB Board, in 2018 the International Accounting Standards Board (IASB) revised the conceptual framework and rejected the concepts of conservatism and prudence on the grounds that these concepts were not in accordance with neutrality, one aspect from faithful representation. Caution (prudence).

\subsection{Earning Management}

Sugiyanto and Etty 2018 Earning management is every action taken by management to understand earning management, including: First Understanding earnings management as the opportunistic behavior of managers to maximize their utility in dealing with compensation, debt, and political cost contracts. Second, Looking at earning management from the perspective of efficient contracting, meaning that earning management gives managers a flexibility to protect themselves and the company in anticipating unexpected events for the benefit of those involved in the contract. The concept of accruals consists of discretionary accruals and non- discretionary accruals. Discretionary accrual is the recognition of accrual earnings or expenses that are free, unregulated, and is a choice of management policy, while non- discretionary accruals are recognition of accrual earnings that are reasonable, unaffected by management policies, and subject to a standard or accounting principle generally accepted, and if the standard the violation will affect the quality of financial statements (Sugiyanto, at al, 2018).

\subsection{Return Saham}

The importance of measuring company performance can be explained by agency theory. According to agency theory, the principal as the owner of the company and the agent as the management of the company are very dependent on the performance of the company Jensen and Meckling, 1976 (Sugiyanto and Etty 2018). Management as an agent aims to provide wealth to the principal or owner of the company. In this connection the principal demands the return of investments entrusted to be managed by management. Acheampong et al (2017) states that returns show financial rewards obtained as a result of investing. The nature of the return depends on the form of investment. For example, companies that invest in fixed assets and business operations expect returns in the form of profits before interest and taxes and in the form of increases in cash flow. Investors who buy common stocks expect returns in the form of dividend payments and capital gains (if the stock price increases), while investors who buy corporate bonds expect interest payments. Then, returns are associated with shares owned by investors. 


\subsection{Research Hypothesis}

Based on the description, the alternative hypothesis is as follows: H0: Intellectual capital has no effect on future stock returns.

H1: Intellectual capital affects the future stock return. H0: Conservatism has no effect on Future Stock Return. H2: Conservatism influences Future Stock Return.

H3: Sudden earnings management influences future stock returns. H3: Management earnings affect future stock returns.

H0: Intellectual Capital, Conservatism, and Earning management have no effect simultaneously on future stock returns

H4: Intellectual Capital, Conservatism, and Earning management simultaneously influence the future stock return

H0: Stock returns have no effect on future stock returns. H5: Stock returns affect future stock returns.

\section{Research Methodology}

\subsection{Population and Sample Research Methodology}

The population used in this study is a mining company that is listed and publishes its annual report on the Indonesia Stock Exchange (IDX) for the period 2013-2018. While the sampling in this study uses a purposive sampling method, namely sampling is limited to certain criteria or considerations that can provide the desired information in accordance with selected criteria

A. Operationalization of Research Variables This study uses 5 variables, namely 1

dependent variable and 4 independent variables. 1. Dependent Variable Future Stock Return This study calculates future stock returns using Nurrohman and Zulaikha's research (2016). calculate the total return by calculating in calculating return $t+1$ (one year in the future). Future stock returns are calculated using the formula below:

$$
F_{S R}+\mathbf{1}=\mathbf{P t}_{\mathbf{t}+\mathbf{1}}-\mathbf{P}_{\mathbf{t}}+\mathbf{D}_{\mathbf{t}+\mathbf{1}}
$$

\section{Variabel Independen \\ a. Intellectual Capital}

Formulation and calculation phases is to calculate the value added or value added (VA) is the difference between sales (OUT) and input (IN). The formula for calculating VA is (Pulic, 1998 in Wanto, 2016) as follows: This formulation is the number of coefficients mentioned earlier. The result is a new and unique indicator, the VAIC TM, which is as follows:

$$
V A I C^{\mathrm{TM}}=\mathrm{VACA}+\mathrm{VAHU}+\mathrm{STVA}
$$

Keterangan:

VAIC $^{\text {TM }}=$ Value Added Intellectual Coefficient 
VACA $=$ Capital employed

efficiency VAHU $=$ The Human Capital

Coefficient STVA $=$ Structural Capital

Coefficient

\section{b. Conservatism}

Accrual-based Conservatism (CONACC). Conservatism based on accruals is calculated by adding up net income before the company's extraordinary items in year $t$ with depreciation expense and subtracting operating cash flow and divided by average total assets (Ahmed and Duellman, 2017). as follows:

$$
\text { CONACC }_{\text {it }}=\frac{\text { Akrual }(i t)}{3 \text { tahun }}
$$

\section{c. Earning Management}

Earning management is an action taken intentionally the financial reporting process aimed at the external company with the aim of generating personal benefits for some parties, in this case the company. Earning management is proxied by discretionary accruals (discreation worksccrual). Earning management measurements using Sugiyanto and Etty's research (2018) discretionary accruals (discretionary accruals) formula produced by the Kaznik model (1999) regression model as follows:

$$
\text { TAC }=\beta 0+\beta 1(\triangle R E V i t-\triangle R E C i t)+\beta 2 P P E i t+\beta 3 " C F O i t+\varepsilon
$$

\section{d. Return Saham}

Return is the overall return of an investment in a certain period, consisting of capital gain (loss) and yield. Capital gain (loss) is the difference from the current investment price relative to the price of the previous period. calculate stock returns using total return. This study calculates total returns by adding up capital gains (losses) and stock yield dividends in accordance with Nurrohman an Zulaikha's calculations (2013).

$\mathrm{RS}=\mathrm{P}(\mathrm{t})-\mathrm{P}(\mathrm{t}-1)+\mathrm{D}(\mathrm{t}) / \mathrm{P}(\mathrm{t}-1)$

The Analysis and Hypothesis Test Design is formulated as follows $\mathrm{Y}=\alpha+\beta 1 \mathrm{X} 1+\beta 2 \mathrm{X} 2+\beta 3 \mathrm{X} 3+\mathrm{Z}+\mathrm{e}$

Keterangan:

$\mathrm{Y}=$ Future Stock Return $\alpha=$ Konstanta $\beta 1, \beta 2, \beta 3=$ Koefisien regresi, $\mathrm{X} 1=$ Intellectual Capital X2 = Conservatism. X3 = Earning, Management, $\mathrm{Z}=$ Return Saham. $\mathrm{e}=$ error

\section{e. Model Regresi Data Panel}

In making panel data regression, we can combine three approaches, namely the common effect 
approach, the fixed effect approach and the random effect approach.

Model analisis Common Effect (Pooling Least Square), Pendekatan Fixed Effect,

Pendekatan Random Effect

Random Effect (efek random) digunakan untuk mengatasi kelemahan metode efek tetap yang menggunakan variabel semu, sehingga dapat dituliskan dalam persamaan :

$\beta 0=\beta 0+u i, i=1, \ldots, n$ b8

sehingga persamaan model yang digunakan adalah :

$\mathrm{Yit}=\beta 0 \mathrm{i}+\beta 1 \mathrm{Xit}+\beta 2 \mathrm{Xit}+\mathrm{ui}+\varepsilon \mathrm{it}$

Yit $=$ Variabel dependen pada unit observasi ke $-\mathrm{i}$ dan waktu ke $-\mathrm{t}$

Xit $=$ Variabel independen pada unit observasi ke $-\mathrm{i}$ dan waktu ke

- $\mathrm{t} \beta 0 \mathrm{i}=$ Intersep model regresi pada unit observasi ke $-\mathrm{i}$

ui $=$ komponen error pada unit observasi ke - i

$\varepsilon$ it $=$ komponen error pada unit observasi ke $-\mathrm{i}$ dan waktu ke $-\mathrm{t}$

\section{f. Model Regresi test}

1) Uji Chow

In making panel data regression, we can combine three approaches, namely the common effect approach, the fixed effect approach and the random effect approach

Chow $=\mathrm{N}-1 \mathrm{NT}-\mathrm{N}-\mathrm{K}$

\section{2) Asumsi Klasic Test}

Classical assumption testing is needed to fulfill the BLUE (best linear unbiased estimator) requirements, ie there is no heteroscedasticity, there is no multicollinearity, and there is no autocorrelation. Uji Heteroskedastisitas, Uji Multikolinearitas, Uji Autokorelasi, Uji Normalitas, Hipotesis test.

\section{Results and Discussion}

\subsection{Discussion and Research Results}

Overview of Research Objects Researchers took samples, namely, mining companies listed on the Indonesia Stock Exchange in 2013- 2018. Of the 39 companies representing mining companies, there were 14 companies that conducted IPOs in the 2013-2018 period so that the data needed in the study was incomplete, and there were companies that reported negative earnings that did not match the sample criteria. So that the research sample of 14 mining companies totaling 84 samples.

Description of Research Samples In this study, the sample was selected using the purposive sampling method using predetermined criteria. Samples were selected for mining and property companies listed on the Indonesia Stock Exchange. The sample selection is based on the following criteria:Analysis of Research Results Descriptive Data Statistics the following is a general description of the data in Descriptive Statistics using Eviews 10 in table 1: 
Table 1. Deskriptif Statistik

\begin{tabular}{lcccc}
\hline & $\begin{array}{c}\text { Futrure Stock } \\
\text { Return }\end{array}$ & $\begin{array}{c}\text { Intelctual } \\
\text { Capital }\end{array}$ & Conservatisme & Earning Management \\
\hline Mean & 0.020013 & 6.338549 & -0.201914 & 0.112118 \\
Median & 0.009800 & 6.186600 & -0.117800 & 0.084700 \\
Maximum & 0.192200 & 11.68520 & 0.058700 & 0.638200 \\
Minimum & 0.001100 & 1.198600 & -0.976200 & -0.029000 \\
Std. Dev. & 0.032504 & 2.588138 & 0.223034 & 0.109226 \\
Skewness & 3.664928 & 0.038703 & -1.634637 & 2.262963 \\
Kurtosis & 17.41646 & 2.352435 & 4.993251 & 10.79782 \\
& & & & \\
Jarque-Bera & 915.4637 & 1.488662 & 51.31420 & 284.5150 \\
Probability & 0.000000 & 0.475052 & 0.000000 & 0.000000 \\
Sum & 1.681100 & 532.4381 & -16.96080 & 9.417900 \\
Sum Sq. Dev. & 0.087693 & 555.9720 & 4.128762 & 0.990209 \\
Observations & 84 & 84 & & 84 \\
\hline
\end{tabular}

From the descriptive statistics table in table 1, it can be explained that the sample companies are using the pooled data method in which 14 companies during the observation period (6 years) so that the samples used are 84 showing the mean, median, maximum value, minimu value, and standard deviation. The standard deviation of each variable looks smaller than the mean, so the data deviation can be said to be good. It can be explained that from the sample companies using the pooled data method in which 14 companies were multiplied by the study period.

\subsection{Choosing the Panel Data Regression Model}

The model used in this study is panel data regression, to test the model specifications and the suitability of theories with reality. Ordinary lest square model (OLS) or common effect model (CEM) Hausman Test (Fixed Effect Random Effect).

Table 2. Hausman test

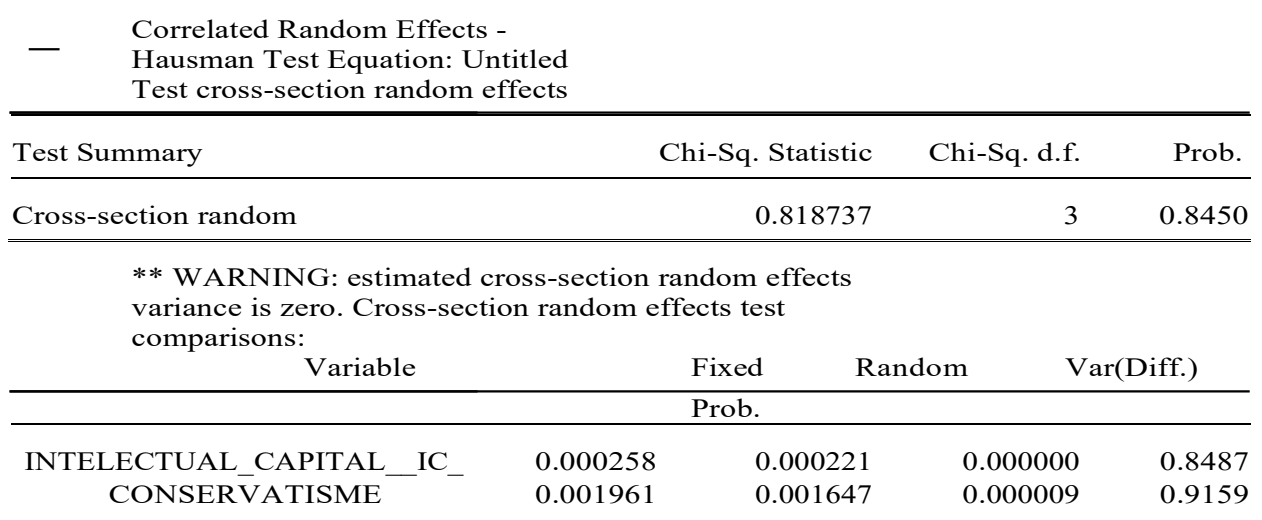




\begin{tabular}{|c|c|c|c|c|}
\hline EARNING_MANAGEMENT & 0.010437 & 0.012896 & 0.000008 & 0.3741 \\
\hline \multicolumn{5}{|c|}{$\begin{array}{l}\text { Cross-section random effects test } \\
\text { equation: Dependent Variable: } \\
\text { FUTURE_STOCK_RETURN Method: } \\
\text { Panel Least Squares } \\
\text { Date: } 11 / 01 / 19 \text { Time: } \\
\text { 22:49 Sample: } 2013 \\
2018 \\
\text { Periods included: } 6 \\
\text { Cross-sections included: } 39 \\
\text { Total panel (balanced) observations: } 234\end{array}$} \\
\hline Variable & Coefficient & Std. Error & t-Statistic & Prob. \\
\hline $\mathrm{C}$ & -0.001444 & 0.001624 & -0.888785 & 0.3752 \\
\hline $\begin{array}{l}\text { INTELECTUAL_CAPITAL__ IC } \\
\text { CONSERVATISME } \\
\text { EARNING_MANAGEMENT }\end{array}$ & $\begin{array}{l}0.000258 \\
0.001961 \\
0.010437\end{array}$ & $\begin{array}{l}0.000310 \\
0.003687 \\
0.005457\end{array}$ & $\begin{array}{l}0.831376 \\
0.531984 \\
1.912649\end{array}$ & $\begin{array}{l}0.4068 \\
0.5954 \\
0.0573\end{array}$ \\
\hline \multicolumn{5}{|c|}{ Effects Specification } \\
\hline \multicolumn{5}{|c|}{ Cross-section fixed (dummy variables) } \\
\hline $\begin{array}{l}\text { R-squared } \\
\text { Adjusted R-squared } \\
\text { S_E of regression }\end{array}$ & $\begin{array}{r}0.174787 \\
-0.001430 \\
0009262 \\
\end{array}$ & \multicolumn{2}{|c|}{$\begin{array}{l}\text { Mean dependent var } \\
\text { S.D. dependent var } \\
\Delta \text { kaike info_criterion }\end{array}$} & $\begin{array}{r}0.000438 \\
0.009255 \\
-6364706 \\
\end{array}$ \\
\hline $\begin{array}{l}\text { Sum squared resid } \\
\text { Log likelihood } \\
\text { F-statistic } \\
\text { Prob(F-statistic) }\end{array}$ & $\begin{array}{l}0.016470 \\
786.6705 \\
0.991885 \\
0.492305\end{array}$ & \multicolumn{2}{|c|}{$\begin{array}{l}\text { Schwarz criterion } \\
\text { Hannan-Quinn criter. } \\
\text { Durbin-Watson stat }\end{array}$} & $\begin{array}{r}-5.744520 \\
-6.114647 \\
2.798206\end{array}$ \\
\hline
\end{tabular}

Source: Output data processed Eviews 10.0 (2019)

Source: Eviews 10.0 panel data output (2019) The results of the test table above can be seen that the random cross section probability value is 0.8450 or $>0.05$, then the panel data regression used in this study is the Random Effect Model better than the Fixed Effect Model (FEM).

\section{a. Model Conclusions}

Based on paired testing of the three panel data regression models in table 2, it can be concluded that the fixed effect model in panel data regression is used further in estimating the factors that influence future stock returns on Intelectual Capital, Conservatism and Earning management at the Indonesia Effect Exchange during the research observation period.

Table 3. Overview of Panel Data Regression Model Testing

\begin{tabular}{|c|c|c|c|c|c|}
\hline No & Met & & Testing & & Result \\
\hline 1 & Chow-Test & & $\begin{array}{l}\text { Common effect vs } \\
\text { Fixed Effect }\end{array}$ & & Common Effect \\
\hline 2 & $\begin{array}{l}\text { Langrange } \\
\text { (LM-Test) }\end{array}$ & Multiplier & $\begin{array}{l}\text { Common Effect vs } \\
\text { Random Effect }\end{array}$ & & Common Effect \\
\hline 3 & Husman Test & & $\begin{array}{l}\text { Fixed Effect } \\
\text { Random Effect }\end{array}$ & $v s$ & Random Effect \\
\hline
\end{tabular}




\section{a. Panel Data Classic Assumptions Test}

A regression model will provide reliable results if the model used passes the classic assumption test. Jarque-Bera values are not significant (smaller than 2), hence the data are normally distributed. If the probability is greater than $5 \%$, then the data is normally distributed. (Wing Wahyu Winarno, 2016: 5.43). The output of the panel data normality regression test in Figure 4.1 of this study, is shown by the following histogram:

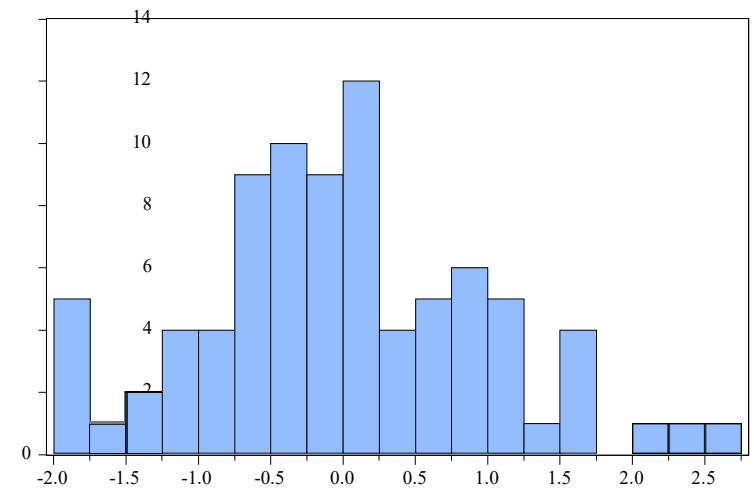

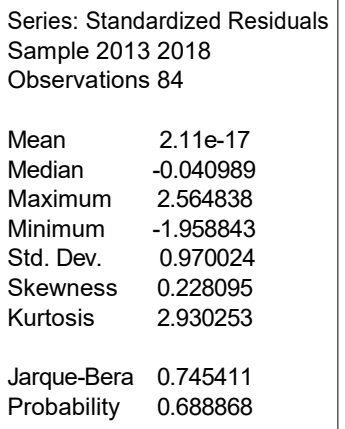


Fig.1.1nHistrogram Normality Test

The results of the Histogram in Figure 4.1 above show a Jarque-Bera value of $0.745411<2$, and a probability of $0.688868>0.05$ so that it can be concluded that the residuals are normally distributed which means the classical assumptions about normalcy have been fulfilled.

\section{b. Multicollinearity Test}

Multicollinearity Test aims to test whether there is a correlation between the independent variables (independent) in the regression model.

Table 4. Multikolinearitas test

\begin{tabular}{cccc}
\hline & $\begin{array}{c}\text { Intelectual } \\
\text { Capital }\end{array}$ & Conservatism & Earning \\
\hline Intelectual & 1.000000 & 0.105377 & 0.075093 \\
Capital & 0.105377 & 1.000000 & -0.032963 \\
Conservatism & 0.075093 & -0.032963 & 1.000000 \\
Earning & & Source: Output data processed Eviews $10.0(2019)$ \\
Mangement & &
\end{tabular}

The results of the multicollinearity test output above, it can be seen the value of each correlation coefficient of the independent variable is less than 0.9 , then the tested model is free

\section{c. Autocorrelation Test}

This autocorrelation test was performed by comparing the Durbin Watson values. If the Watson Durbin Test value is between 1.54 and 2.46 then there is no autocorrelation (Wing Wahyu Winarno, 2016: 5.28). The results of the Durbin Watson Test in the regression analysis with the fixed effect model (table 4.11) are 1.972307, between 1.54 and 2.46 so that this regression model does not occur in autocorrelation.from multicollinearity.

\section{d. Uji Heterokedastisitas}

This heterokedasticity test aims to test whether in the regression model there is an unequal variance from the residuals of one observation to another.

Table 5. Uji Heterokedastisitas

Heteroskedasticity Test: Glejser

\begin{tabular}{llll}
\hline F-statistic & 2.548751 & Prob. F(3,80) & 0.0616 \\
Obs*R-squared & 7.328153 & Prob. Chi-Square(3) & 0.0621 \\
Scaled explained SS & 12.98317 & Prob. Chi-Square(3) & 0.0047 \\
\hline \hline
\end{tabular}


Test Equation:

Dependent Variable: ARESID

From table 5 above it can be seen that there are changes, where there are independent variables experiencing statistical significance. The changes that occur result from the consistency of error variance which shows that in the initial model there was heterokedasticity. The significance value of $0.061605>0.05$, which means that the variation of the bound model in the Future Stock Return model can be explained by the independent variables Intellectual capital, Conservatism, Earning Management, so that heterocedasticity problems are not expected.

\section{e. Equation Regression Model}

This research with panel data regression was used to see the effect of the independent variables Intellectual capital, conservatism, earnings management on future stock returns implying the stock returns, using Eviews 10.0 software, the following output model is used.

Table 6. Model Fixed Effect

Dependent Variable: Future Stock Return Y

Method: Panel Least Squares

Date: 10/25/19 Time: 16:26

Sample: 20132018

Periods included: 6

Cross-sections included: 14

Total panel (balanced) observations: 84

\begin{tabular}{lrlrr}
\hline \multicolumn{1}{c}{ Variable } & Coefficient & Std. Error & t-Statistic & Prob. \\
\hline Intelectual_C & -0.085883 & 0.042270 & -2.031752 & 0.0045 \\
Conservatism & 1.816193 & 0.489396 & 3.711091 & 0.0004 \\
Earning_M & -3.118954 & 0.996575 & -3.129673 & 0.0024 \\
C & -3.343320 & 0.325186 & -10.28126 & 0.0000 \\
\hline R-squared & 0.260255 & Mean dependent var & -4.604099 \\
Adjusted R-squared & 0.232514 & S.D. dependent var & 1.127824 \\
S.E. of regression & 0.988044 & Akaike info criterion & 2.860269 \\
Sum squared resid & 78.09849 & Schwarz criterion & 2.976022 \\
Log likelihood & -116.1313 & Hannan-Quinn criter. & 2.906801 \\
F-statistic & 9.381787 & Durbin-Watson stat & 1.428485 \\
Prob(F-statistic) & 0.000022 & & \\
\hline
\end{tabular}

Source: Output Eviews data diolah

Based on the regression results above, we obtain the following linear regression equation: $\mathrm{Y}=$ $-3.343320+-0.085883$ IC +1.816193 Conservatism +-3.118954 Earning Management $+\square$ it 
From the above equation can be explained as follows:

1) Hypothesis Testing with Panel Data Regression Analysis

2) Partial hypothesis testing using the t test, stated in the output of the fixed effect model is explained as follows:

\subsection{Discussion of Research Results}

a) Intellectual capital has a significant effect on future stock returns, after getting a result of 0.0045 smaller than the required level of $05 \%$, then in the regression equation that intellectual capital has a significant effect on future stock returns. This shows that intellectual capital has a strong contribution to increase the company's future stock return. The results of this regression are the same as the results of the 2018 Bontis and Ulum research which states that Physical Capital intellectual capital has a significant effect on future stock returns.

b) Conservatism has a significant effect on future stock returns, the statistical result is 0,0004 smaller with the required $05 \%$. The results of the study are reinforced by the theory of information assimetry which states that the company's productive future stock returns will affect future stack returns. The regression results are in line with the results of Sugiyanto and Etty 2018 research that conservatism influences future stock returns.

c) Earning management has a significant effect on future stock returns to get 0.0024 results smaller than $0.5 \%$, the results of the regression equation that earning management is very burdensome Agent or management in managing corporate profits that provide added value to obtain earning management. The results of the study were strengthened by the theory agency Jensen and Makling 1976 in Sugiyanto 2017.

d) Simultaneous results Intellectual capital, conservatism, earnings management simultaneously affect future stock returns. These findings indicate that in the sample companies, intellectual capital, conservatism, earnings management simultaneously contributed a strong significance value of 0,0003 or the remaining $3 \%$ was influenced by other factors.

e) Implications of future stock returns on stock returns. These findings indicate that in sample companies, future stock returns on stock returns have implications, according to Agency theory which emphasizes accounting earnings and accuracy in determining stock returns. Based on the test results and statistical analysis and interpretation of the test results, it was concluded that the mining sector companies did not have implications for stock returns.

\section{Conclusions}

Conclusion based on the test results and discussion as presented in the previous section, several conclusions can be drawn:

a) Intellectual capital has a significant effect on future stock returns, after getting the results of the regression equation it turns out that intellectual capital has no significant effect on future stock returns.

b) Conservatism has a significant effect on future stock returns. These results are 
consistent with the theory of information assimetry which states that future stock returns are productive companies. The regression results are in line with the results of Sugiyanto and Etty 2018 research that conservatism influences future stock returns.

c) Earning management has a significant effect on future stock returns after getting the results of the regression equation, which shows that earning management has a positive and significant effect on future stock returns.

d) Simultaneous results Intellectual capital, conservatism, earnings management simultaneously affect future stock returns. in accordance with the Signaling theory which explains that companies can maintain productivity with the company's competitive advantage by implementing strategies to create value added.

e) Implications of future stock returns on stock returns. The results of future stock returns on stock returns have implications for it according to Agency theory.

\section{References}

[1] Acheampong, P., Agalega, E. dan Shibu, A.K. 2014."The Effect of Financial Leverage and Market Size on Stock Returns on the Ghana Stock Exchange: Evidence from Selected Stock in the Manufacturing Sector." International Journal of Financial Research,

[2] Adityo. 2017. “ Analisis Pengaruh Corporate Responbility, Beta, Firm Size, dan Book to Market Ratio terhadap Return Sahamn (Studi Kasus Perusahaan Manufaktur yang terdaftar di BEI periode 2010-2011 )". Skripsi. Universitas Diponegoro.

[3] Aisyah, Istiqomah dan Desi Adhariani. 2017. "Pengaruh Manajemen Laba Terhadap Stock Return Dengan Kualitas Audit Dan Efektivitas Komite Audit Sebagai Variabel Moderasi”. Universitas Indonesia, Depok.

[4] Agnes Utari Widyaningdyah dan Y. Anni Aryani 2017 Jurnal Akuntansi dan Keuangan, Intellectual Capital dan Keunggulan Kompetitif Vol. 15, No. 1, Mei 2017

[5] Amarjit Gill, Nahum Biger, Harvinder S. Mand, and Neil Mathur (2016) Earnings Management, Firm Performance, and the Value of Indian Manufacturing Firms International Research Journal of Finance and Economics. ISSN 1450-2887 Issue 116 November, 2016.

[6] Beylin, Ilya. 2017. "Tax Authority As Regulator And Equity Holder: How Shareholder' Control Right Could Be Adapted To Serve The Tax Authority. Vol. 84;851.Chen J, Zhu Z, dan Xie HY. (2004). Measuring Intellectual Capital: A New Model and Empirical Study", Journal of Intellectual Capital. 5(1): 238-247

[7] Bontis, N. 2000. "Intellectual Capital and Bussiness Performance in Malaysian. Industries,". Journal of Intellectual Capital, 1 (1): 85-100

[8] Brennan, N. dan Connell, B. 2016, "Intellectual capital: current issues and policy implications",Journal of Intellectual Capital, Vol. 1 No. 3, pp. 206-40.

[9] Chen J, Zhu Z, dan Xie HY. 2014. "Measuring intellectual Capital: A New Model and Empirical Study.”, Journal of Intellctual Capital. (5(1); 238-247

[10] Dechow, Patricia 1995. "Detecting Earnings Management. The Accounting Review", April Vol. 70 No.2.

[11] Firer, S dan Williams, M. 2013. "Intellectual Capital and Traditional Measures of. Corporate Performance". Journal of Intellectual Capital. Vol. 4 No. 3, pp. 348-.

[12] Febrianti, F.D. 2017, "Pengaruh Konservatisme Akuntansi, Real Earnings Management dan Information Asymetry Terhadap Return Saham”. Universitas Islam Negeri Syarif Hidayatullah Jakarta. Jakarta.

[13] Ghozali, Imam. 2017. "Aplikasi analisis Multivariate dengan Program SPSS", Penerbit Universitas Diponegoro, Semarang. 
[14] Grant, R.M., 2017. "The Resource-Based Theory of Competitive Advantage: Implications for Strategy Formulation. California Management Review"; 33, (3), pp. 114-135.

[15] Goodfrey, Jayne, Allan Hodgson, Ann Tarca, Jane Hamilton, and Scott Holmes.V“Accounting Theory". 7th Ed. John Wiley \& Sons. 2017.

[16] Gumanti, T. A. 2014. "Earnings Management: Suatu Telaah Pustaka. Jurnal Akuntansi dan Keuangan", 2(2), 99-104.

[17] Harvey, Campbell R. dan Akhtr Siddiqu. 2014. "Conditional Skewness in sset Pricing Test". Journal pf Finance 55, 1263-1296.

[18] Hastuti, S. 2011. "Titik Kritis Manajemen Laba pada Perubahan Tahap Life Cycle Perusahaan: Analisis Manajemen Laba Riil dan Manajemen Laba Akrual”. Simposium Nasional Akuntansi XIV Aceh. Universitas Syiah Banda Aceh.

[19] Healy, P.M., and J.M. Wahlen. 1999. "A Review of The Earnings Management. Literature and Its Implications for Standard Setting”. Accounting Horizons. Vol. 13 (4) : 365-383.

[20] Herawaty, V. 2018. "Peran Praktek Corporate Governance Sebagai Moderating Variabel Dari Pengaruh Earnings Management Terhadao Nilai Perusahan". Jurnal Akuntansi dan Keuanfan. 10(2), 90-97

[21] Hidayati, S. M. dan Zulaikha. 2013. "Analisis Perilaku Earning Management : Motivasi Minimalisasi Income Tax". Simposium Nasional Akuntansi VI. Surabaya.

[22] Hussainey, Khaled. 2017. "The Impact of Audit Quality on Earnings Predictability”.Managerial Auditing Journal24 (4), pp. 340-351.

[23] Ihyaul Ulum (2018) Program Studi Magister Sains Akuntansi Program Pascasarjana Universitas Diponegoro Semarang

[24] Indah dan Warganegara.(2013). "Pengaruh Intellectual Capital Terhadap Kinerja Keuangan Pada Sub Sector Restaurant, Hotel and Tourism Perusahaan yang Terdaftar Di Bursa Efek Indonesia Tahun 2007 - 2011".

[25] Indrayanti, Ni Putu Ayu Desy dan Made Gede Wirakusuma. "Pengaruh Manajemen Laba Pada Return Saham Dengan Kualitas Audit Dan Corporate Governance Sebagai Variabel Pemoderasi". E-Jurnal Akuntansi Universitas Udayana, Bali.

[26] Irmawati, Dinar. 2018. "Pengaruh kualitas audit terhadap kemampuan memprediksi laba dengan model Collins et.al (1994)”. Skripsi. Universitas Diponegoro.

[27] Jackson, E., dan Schuler, R. 1995. "Understanding Human Resource Management in the Context of Organizations and Their Environment”, Annual Review Psychology 46, 237-264

[28] Jeffrey L. Callen, Mozaffar Khan, dan Hai Lu. 2016. “Accounting Quality, Stock Price Delay and Future Stock Returns". University of Toronto

[29] Jensen, M. C and Meckling, W.H. 1976. "Theory of the Firm: Managerial Behavior,Agency Costs and Ownership Structure”. Journal of Financial Economics, Oktober, 1976, V. 3, No. 4, pp. 305-360.

[30] Kinantya Komala Nur Shabrina dan Fuad. 2017. "Pengaruh Kualitas Audit Terhadap Kemampuan Investor Memprediksi Laba Di Masa Depan”. Universitas Diponegoro, Semarang.

[31] Mayangsari. 2016. "Bukti Empiris Pengaruh Spesialisasi Industri Auditor Terhadap Earnings Response Coefficient".Jurnal Riset Akuntansi Indonesia 7 (2), hal. 154- 178.

[32] Mohammadghorban Mehri, ett all - Asian Social Science; Vol. 9, No. 9; 2017 Intellectual Capital and Firm Performance of High Intangible Intensive Industries: Malaysia Evidence

[33] Muhammad Husni Nurrohman dan Zulaikha (2016) Pengaruh Eraning Per Share, Return Saham, Kualitas Audit, dan Hasil Laba Terhadap Return Saham Satu Tahun Ke Depan Volume 2, Nomor 3, Tahun 2016, Halaman 1-9 ISSN (Online): 2337-3806

[34] Nasir Akram (2017) The Effect of Liquidity on Stock Returns : An Evidence From Pakistan IOSR Journal of Business and Management (IOSR-JBM) e-ISSN:2278-487X,p-ISSN:23197668, Volume 16, Issue 2. Ver. I (Feb 2017), PP 66-669 IOSR Journal of Business and Management (IOSR-JBM) e-ISSN:2278-487X,p-ISSN:2319-7668, Volume 16, Issue 2. Ver. I (Feb 2016), PP 66-669

[35] Nurrohman dan Zulaikha. 2017. "Pengaruh Earning Per Share, Return Saham, 
KualitasAudit,danHasilLabaterhadap Return Saham Satu Tahun Ke Depan”.. DiponegoroJournalofAccounting2(3):1-9. ISSN (online) :2337-3806.

[36] Nuryaman. 2017. "The Influence of Earnings Management on Stock Return and the Role of Audit Quality as a Moderating Variable". International Journal of Trade, Economics and Finance

[37] Pasaribu, Hiras., Dian Indri Purnamasari., dan Indri Tri Hapsari.2017.”The Role of Corporate Intellectual Capital”. American International Journal of Contemporary Research Vol. 2 No. 9; September 2012.

[38] Pulic, A. (1998). "Measuring The Performance Of Intellectual Potential In Knowledge Economy". Croation-IC Centre.

[39] Pulic, A. (2000), "VAIC of Technology Management, 20 (5-8), 702-714.

[40] Purnomosidhi, Bambang. 2006. "Praktik Pengungkapan Modal Intelektual pada. Perusahaan Publik di BEJ.” Jurnal Riset Akuntansi Indonesia. Vol 9, No.1.

[41] Rahayu dan Darmawati. 2016. "Pengaruh Kualitas Audit TerhadapHubungan Earnings Management DanReturn Saham", Media Riset Akuntansi, Auditing \& Informasi, Vol.1 1 No.2.

[42] Reyther Biki, R. A. Damayanti, Grace T. Pontoh (2016) Pengaruh konservatisme akuntansi terhadap asimetri informasi dimoderasi kepemilikan manajerial dan kepemilikan institusional Jurnal Analisis, Desember 2013, Vol.2 No.2: 162-170 ISSN 2303-100X

[43] Sekaran, Uma. (2017). Research Methods for business- A Skill Building Approach" Edisi 7.

[44] Setiawan W, Liswam. 2017. "Pengaruh Workload dan Spesialisasi Auditor Terhadap Kualitas Audit Dengan Kualitas Komite Audit Sebagai Variabel Pemoderasi”. Jurnal Akuntansi dan Keuangan Indonesia, Vol.8 No 1

[45] Setiawati, Lilis.2012. "Manajemen Laba dan IPO Di bursa Efek Jakarta”. Jurnal. Akuntansi dan Manajemen, hal 1-16.

[46] Selvi Melida Salim dan Golrida Karyawati (2018) Pengaruh Modal Intelektual terhadap Kinerja Keuangan

[47] Suhardjanto, D dan Wardhani. 2017. "praktik intellectual capital disclosure perusahaan yang terdaftar di bursa efek Indonesia". Universitas Sebelas Maret: Solo

[48] Simanjuntak, Piter. 2018. "Pengaruh Time Budget Pressure dan Resiko Kesalahan terhadap Penurunan Kualitas Audit". Tesis. Universitas Diponegoro Semarang.

[49] Sriranga Vishnu dan Vijay Kumar Gupta (2017) Intellectual Capital and Performance of Pharmaceutial Firms in India Journal of Intellectual Capital Vol 15 No 1, 2017. pp 83-99. Emerald Group Publishing Limited 1469-1930

[50] www.emeraldinsight.com/1469-1930.htm

[51] Sloan, R. G. 1996. "Do Stock Prices Fully Reflect Information in Accruals and Cash. Flows About Future Earnings?". The Accounting Review 71: 289-315

[52] Sugiyanto, 2017 Conservatisme Accounting, Real Earnings Management and Information Asymmetry on Share Return Iternational Journal of Core Engineering \& Management ( ISSN: 2348-9510, Vol-4, Issue-*, November-2017

[53] Sugiyanto 2018 Effect Ratio Keuangan Perusahaan Pada Model Prediksi Kepailitan Perbankan Model Altman Z-Score dengan Moderasi Good Corporate Governance http://iai.Jabar. Parade Riset Akuntansi.ac.id Parade Riset Akuntansi III (PRA) 2018

[54] Sugiyanto 2018 Good Corporate Governance Conservatisme Accounting, Real Earnings Management and Information Asymmetry on Share Return Prosiding Seminar Internasional Seminar IAI Jabar dan Coll For Papers RISET AKUNTANSI di Universitas Pamulang, 21 April 2018

[55] Tarigan, Timotious. 2017. “Analisis Pengaruh Intellectual Capital Terhadap Kinerja Perusahaan Sector Farmasi Yang Terdaftar Di Bursa Efek Indonesia Tahun 2006- 2010". Skripsi Universitas Diponegoro: Semarang.

[56] Tarigan, Juliana dan S. V. Siregar. 2014. "Analisis Hubungan Manipulasi Akti- vitas Riil dan Kinerja Operasi Masa Depan: Bukti dari Pencapaian Earnings Benmarck”. SNA 17 Mataram Lombok. Universitas Mataram 
[57] Tendi Wanto (2016) Pengaruh Modal Intelektual Terhadap Manajemen Laba Riil Dan Future Stock Return Media Riset Akuntansi, Auditing \& Informasi, Vol.16 No.2 September 2016 ISSN 0852-1875

[58] Ulum, Ihyaul. 2018. "Intellectual Capital Performance Sektor Perbankan di. Indonesia". Jurnal Akuntansi dan Keuangan, Vol. 10, No. 2.

[59] Uswati, Luluk dan Sekar Mayangsari. 2017. "Pengaruh Manajemen Laba Terhadap Future Stock Return Dengan Asimetri Informasi Sebagai Variabel Moderating”. Fakultas Ekonomi Universitas Trisakti, Jakarta.

[60] Vestari, M. 2017. "Pengaruh Earnings Surprise Benmark Terhadap Prediktabilitas Laba dan Return Saham".Preatasi 9(1). ISSN 1411-1497

[61] Wanto, Tendi. 2016. "Pengaruh Modal Intelektual Terhadap Manajemen Laba Riil dan Future Stock Returns".Media Riset Akuntansi, Auditing \& Informasi, Vol. 16

[62] Wibowo, Arie dan Hilda Rossieta. 2017. "Faktor-Faktor Determinasi Kualitas Audit - Suatu Studi dengan Pendekatan Earnings Surprise Benchmark". Jurnal Ilmu akuntansi, Fakultas Ekonomi. Universitas Indonesia.

[63] Vishnu, Sriranga., dan Vijay Kumar Gupta. (2017). "Intellectual Capital And Performance Of Pharmaceutical Firms In India”. www.emeraldinsight.com/1469- 1930.htm

[64] Yuskar, dan Novita, D. "Analisis Pengaruh Intellectual Capital Terhadap Nilai Perusahaan Dengan Kinerja Perusahaan Sebagai Variabel Intervening Pada

[65] Perusahaan Perbankan di Indonesia”. Jurnal Manajemen dan Bisnis Sriwijaya. Vol 12, No.4, 331-356. 2014. 